\title{
Mitä on laatu ammatillisessa aikuiskoulutuksessa?
}

\author{
Esimerkkinä työvoimakoulutus
}

Työvoimapoliittisen aikuiskoulutuksen laadun ja vaikuttavuuden arvioinnin merkitys lisääntyi ns. ostojärjestelmään siirtymisen myötä vuoden 1991 alusta. Koulutusta hankkivat työvoimaviranomaiset (piiri tai yksittäinen toimisto) kilpailuttavat koulutuksen järjestäjiä ja tekevät tarjousten pohjalta ostopäätöksen parhaan hinta-laatu -suhteen perusteella. Uudistusta suunniteltaessa katsottiin järjestelmän parantavan koulutuksen joustavuutta, laatua ja tehokkuutta. Ko. lakiesityksiä eduskunnassa käsiteltäessä sivistys- ja sosiaalivaliokunnat edellyttivät, että ostopäätös tehdään koulutuksen laadun pohjalta.

Koulutuksen laadun ja vaikuttavuuden arviointikriteerit ovat edelleen kehittymättömiä; käytännössä työvoimakoulutusta hankitaan työhallinnon tuloskriteerien vuoksi edullisimman hinnan perusteella.

Hintapaineista on seurannut ajoittain ennakoimattomia tilanteita kurssien toteutumisessa. Työvoimatoimistoissa koulutukseen ohjaaminen on tullut hankalaksi, eivätkä koulutuksen tarvitsijat voi aina itse suunnitella koulutukseen lähtöään pitkällä tähtäimellä. Opiskelijaryhmien koko on noussut liian suureksi, ja koulutus uhkaa lyhetä "tietoiskuiksi" ja "paketeiksi". Kouluttajien resursseja menee markkinointiin ja myyvien tietopakettien tuottamiseen lyhyellä suunnitteluvälillä.

Työvoimapoliittisen aikuiskoulutuksen laatua mitataan tyytyväisyysarvioinnein ja työhönsijoittumistilastoin. Edelliset riippuvat kuitenkin paljon halovaikutuksesta ja jälkimmäiset suhdanteista. Tuottavuuden keskeinen mittaväline on oppilaspäivän hinta. STK:n työvoimapoliittinen asiamies Pekka Castrén (1992) toteaa, että suurella oppilaspäivien määrällä ja pienillä kustannuksilla päästään halvalla suureen työttö- myyttä vähentävään vaikutukseen koulutusaikana, mutta asetetut tulostavoitteet suosivat työvoimakoulutuksen käyttöä työttömyyden tilapäishoitona. Työvoimapoliittinen aikuiskoulutuslaki antaa mahdollisuuden paremmin räätälöityyn, joustavampaan ja monipuoliseen koulutukseen, mitä edellyttää myös omaksuttu työvoimapoliittinen linja; em. tulostavoitteet eivät tue tätä linjaa.

Eri hallinnonalojen välinen työvoimapoliittisen aikuiskoulutuksen seurantaryhmä kerää tilastotietoa koulutuksen tehokkuudesta, mutta koulutuksen laadun ja vaikuttavuuden kriteereitä ei juuri ole pohdittu

\section{Näkökulmia koulutuksen laatuun ja sen mitattavuuteen}

Pirsigin (1988) mukaan laatu on "tapahtuma, ei olio". Hän kirjoittaa Zen ja moottoripyörän kunnossapito -teoksessaan: "Jokainen Laadun filosofinen selitys on sekä väärä että oikea juuri siksi, että se on filosofinen selitys. Filosofinen selitys muodostetaan analyyttisesti, hajottamalla jokin subjekteiksi ja predikaateiksi. Sitä mitä minä tarkoitan (ja kaikki muut tarkoittavat) sanalla laatu ei voida hajottaa subjekteiksi ja predikaateiksi. Se ei johdu siitä että Laatu olisi niin salaperäistä vaan siitä että Laatu on niin yksinkertaista, välitöntä ja suoraa."

Wittgensteinin mukaan filosofisesti mielenkiintoisia ovat monesti juuri ne käsitteet, joiden määritelmistä tai olemuksesta ollaan epätietoisia. Joka etsii ratkaisua käsitteiden tarkasta määrittelystä, ajaa takaa harhakuvitelmaa. Ongelmallista käsitettä ei voida määritellä, koska sen piiriin lankeavilla ilmiöillä ei ole yhteistä piirrettä. Positivistisen ihanteen mukainen eksakti käsitteenmuodostus ja teoria hämärtää Wittgensteinin mielestä todellisuuden näkemistä. 
Sen sijasta on katsottava läheltä, mitä tapahtuu; tällöin nähdään ensi näkemältä erillisten ilmiöiden välillä monimutkainen yhtäläisyyksien verkko. Yhtäläisyydet muodostavat ikään kuin köyden, jonka säikeet ovat kietoutuneet toisiinsa. Köyden lujuus ei johdu siitä, että jokin säie kulkisi koko köyden läpi, vaan siitä, että monet säikeet ovat peräkkäin punoutuneet toisiinsa (lainaus: Wilenius 1975).

Teesit sopivat hyvin sellaisiin käsitteisiin kuin koulutuksen "laatu", "vaikuttavuus", "tehokkuus" tms. Haitallista tuskin on niinkään ko. käsitteiden pakeneminen näennäisen täsmällistä määrittelyä kuin se, että käytännössä toimitaan ikään kuin tiedettäisiin mistä koulutuksen laadussa tai vaikuttavuudessa on kysymys.

Useimmat käytössä olevat arviointimenetelmät soveltuvat vain tarkoin rajatun ja usein määrällisen tiedon arvioimiseen, joten ne eivät sovellu monien oppimisprosessien ohjaamisen kannalta tärkeiden toimintojen arviointiin. Arviointimenetelmiä on yritetty kehittää irrallisina, opetuksesta ja oppisisällöstä riippumattomina formaaleina "mittareina".

Monikoosteinen ongelma vaatii monimutkaisen ratkaisun: muussa tapauksessa evaluaatio saattaa luoda harhakuvia, jotka tosin voivat olla objektiivisen tuntuisia - tai jopa objektiivisia osatotuuksia - ja ainakin näennäisesti valideja. Päätekäyttäytymis- tms. tuloskriteerit painottavat irrallisten ja erillisten tavoitteiden toteutumista, vaikka koulutuksen monet vaikutukset näkyvät vasta vuosien päästä; toisaalta jollakin irrallisella ja mitattavalla käyttäytymismuodolla on merkitystä vain suhteessa kokonaisuuteen, esim. johonkin laajempaan toimintamalliin (Niinistö 1984).

\section{Tulosajattelu ja kielen menetys}

Kokemukset tulosjohtamisesta osoittavat, miten vaikeaa on laatia valideja mittareita toivottaville tuloksille. Moniuloitteisia laadullisia seikkoja on pakotettu varsin yksioikoisiin muotteihin. Jo itse sana "mittaaminen" viittaa johonkin kvantitatiiviseen ja yksiuloitteiseen, näennäisen eksaktiin (Niinistö, mt.), jolloin tulosten ar- viointi julkisella sektorilla tullee väistämättä jatkossakin olemaan ongelmallinen kysymys.

Mitattaessa organisaation tai työyhteisön toiminnan ulkoisia piirteitä eikä sen sisältöjä ja tuotettuja arvoja patistetaan henkilökuntaa ulkoiseen touhukkuuteen tarkoituksenmukaisen työskentelyn sijasta. Laskentatoimen tutkimus ei ole tuottanut mittoja, jotka ottaisivat työn sisällön huomioon. Liikkeenjohdon tutkijat ovat olleet huolissaan laskentatoimen vakavasta jälkeenjääneisyydestä. Tuottavuuden mittaamisessa käytetään vuosisadan alun massatuotantoon tarkoitettuja malleja. Hyvin vähän on tuotettu tuloksellisuuden muuttuneita ehtoja vastaavia uusia tarkastelutapoja (Virkkunen 1992).

Silloin kun toiminnan toivottavaa tulosta ei voida määritellä sisältä käsin ja sisällöllisin/laadullisin kriteerein, toiminnan omasta logiikasta lähtien, laadullinen tavoite paitsi kutistuu määrälliseksi myös jähmettyy estäen innovaatiot. Omalla logiikalla etenevän tavoitteellisen toiminnan prosessin kuluessa tavoite sitä vastoin elää ja muuttuu. Jos kuvittelemme tietävämme kulttuurin ja yhteiskunnan päämäärät etukäteen, "meillä ei ole mitään käyttöä humanistisille aloille - kuten totalitaarisissa yhteiskunnissa ei tosiasiassa olekaan" (Rorty 1991).

Näyttää siltä, että olemme hyvää vauhtia kadottamassa kielen, jolla voimme keskustella koulutuksesta muuten kuin tuloksellisuuden ja mitattavuuden termein. 1980-luvun puolivälistä koulutuspoliittinen retoriikka on Silvosen (1992) mukaan kokenut käänteen kohti "tehokkuuden" tai "markkinoiden" diskurssia. Toiskallio (1992) kirjoittaa: "Opetuksen kehittämispohdinnoissa tulisi 'lähteä kaukaa'. Kaukaisella tarkoitan sellaista mikä on lähellä, mutta jota emme ehkä näe. Miksi emme näe? Siksi, ettei meillä ole kieltä sen näkemiseksi."

Aikuiskasvatustieteen valtavirraksi on jo muodostunut teknis-rationaalinen ajattelutapa, jossa keskeisiä arvoja ovat menetelmien ylivalta ja tehokkuuspyrkimykset (Collins 1991; lain. Pasanen 1992). Kyseenalaistamalla valtaan ja diskurssiin kätkeytyneet itsestäänselvyydet opettajat ja hallintoihmiset voivat rakentaa oman teoreettisen viitekehyksensä siitä, mikä opetuksen todellinen tarkoitus voisi olla (Aronowitz ja Giroux 1991). 


\section{Eriarvoisuus ja työelämäsuhteen muutos}

Koulutuksen tehokkuuden ja tulosten mitattavuuden painottaminen voi lisätä eriarvoisuutta aikuiskoulutuksen eri tarvitsijaryhmien välillä. Toisaalta on epäilty, voiko tasa-arvopolitiikkaa toteuttaa koulutuksen avulla. Koulutussosiologisesta näkökulmasta koulutus ei luo yhteiskunnan rakenteita vaan uusintaa niitä vahvistaen osaltaan eriarvoisuutta (Kivinen ja Rinne 1991). Onko siis tarpeetonta idealismia kuvitella, että ammatillisen aikuiskoulutuksen keinoin voitaisiin tehdä interventioita ja vaikuttaa syrjäytymiskierteen katkaisemiseen tai työelämäsuhteen uudelleen jäsentämiseen nopeiden muutosten keskellä?

Pyrittäessä arvioimaan aikuiskoulutuksen vaikutuksia yksilölle ja yhteiskunnalle meidän on vaikea hahmottaa samanaikaisesti eri tason merkityksiä. Ongelma on yleisempikin: Giddensin (1981) mukaan sosiaalitutkimuksen eräs keskeinen jännite kulkee vaikeudessa nivoa yhteen mikro- ja makrotason näkökulmia. Yhteiskuntateoria näyttäytyy eri yhteyksissä "vahvana toiminnan suhteen ja heikkona instituutioiden suhteen" tai päinvastoin. Instituutioita ja toimintaa on tarkasteltu duaalisesti toisistaan eroavina ja eriaikaisina, siten niiden yhdistäminen on ollut ongelmallista.

Perinteinen kasvatustiede redusoi sosiaaliset systeemit toiminnan "ympäristöksi", mutta puhtaasti rakenteellinen, esimerkiksi Kivisen ja Rinteen esittämä tarkastelutapa puolestaan redusoi yksilöiden toiminnan rakenteita ylläpitäväksi, harmittomaksi puuhasteluksi. Ihmisten työn ja työelämäsuhteen tarkastelu voi antaa mahdollisuuksia mikro- ja makrotason välisen kuilun kuromiseen.

Haaviston (1991) mukaan työelämäsuhdetta on perinteisesti tarkasteltu yksilöpsykologisesta paradigmasta käsin, jolloin yksilön toiminnan kohde on jäänyt hahmottumatta. "Ihmisen toiminnan mieli on sidoksissa hänen subjektiivisesti määrittämäänsä kohteeseen. Se, miten kohde muodostuu toiminnan motiiviksi, on riippuvainen siitä, miten relevanttia tietoa (ajattelun välineitä, käsitteellisiä työkaluja) yksilöllä on toiminnan mahdollisista kohteista."
Toiminta työelämässä vaatii entistä enemmän samanlaisia taitoja kuin toiminta muussa arkielämässä. Ammatinhallintaan sisältyy entistä enemmän pelkästään yleissivistävinä perusvalmiuksina aiemmin pidettyjä asioita, ja yleissivistävän aikuiskoulutuksen organisaatioiden järjestämä koulutus on mielletty yhä useammin työelämään liittyväksi (Katajisto 1991).

Työelämän muutosten tuomat uudet ammatilliset pätevyysvaatimukset eivät ole kuvattavissa vain yksittäisten tekojen summana - yksittäiset taidot voivat vanhentua nopeasti. Tarvitaan ns. yleisiä työelämätaitoja spesifien, kuhunkin ammattialaan kuuluvien erityistaitojen lisäksi. Yleisiä työelämän vaatimia taitoja voivat olla $\mathrm{mm}$. oppimaan oppiminen, yhteistyötaidot, arvottaminen ja laajeneva vastuuntunto tai kyky jäsentää omaa työelämäsuhdetta muuttuvissa oloissa. Koulutuksen tehtäväksi tuskin voi siten riittää pelkkä tiedonjako, "paketit", vaan ammatillisessa aikuisopiskelussa nousevat tärkeiksi ajattelun, asenteiden ja suhtautumistapojen kehittäminen ja ohjauksellinen, prosessimainen ja projektimainen ote (OECD 1990).

\section{Kohti laadun ongelmaa}

Seuraavassa yritetään hahmotella alustavasti yleistä orientaatiota ammatillisen aikuiskoulutuksen laatukriteereiden jäsentämiseksi pitäen silmällä edellä esitettyjä näkökulmia tulosmittauksesta ja eriarvoisuuden lisääntymisestä.

1. laatukriteeri: Jos laatu on "tapahtuma, ei olio", aikuiskoulutuksen laatua ei voi kuvata abstraktein käsittein, vaan toiminnan tasolla - ei kuitenkaan päätekäyttäytymisenä. Tavoiteltava koulutuksen laatu tulee nähdä konkreettisesti sidoksissa kulloisiinkin tavoitteisiin ja toivottaviin merkityksiin niin työelämän kuin yksilön kannalta; nämä taas tulisi reflektoida hyvin tarkoin ennen koulutuksen aloittamista välttäen pinnallisia ja vanhentuneita, määrälliseen mittausharhaan sidottuja tuloskriteereitä. Työvoimapoliittista aikuiskoulutusta suunniteltaessa ja arvioitaessa tulee olla mukana eri alojen asiantuntijoita.

2. laatukriteeri: Ammatillisen aikuiskoulutuksen tulee tarjota relevantti vastaus työelä- 
män muutokseen ja muuttuviin ammatillisiin pätevyyksiin. Tämä itsestäänselvyys ei ole aina käytännössä itsestäänselvyys. Yhteistyötaitojen, muutosten ennakointikyvyn ja muiden yleisten työelämätaitojen opiskelua palvelee usein parhaiten prosessimainen lähestymistapa. Mitä "prosessi" merkitsee, on kussakin tapauksessa jäsennettävä konkreettisesti. Myös pakettimainen ja tietoiskumainen koulutus voi epäilemättä olla laadukasta, ja sen laatu onkin osin mitattavissa nykyisenkaltaisilla mittareilla. Prosessityyppisen koulutuksen mahdolliset hyödyt ovat yleensä nähtävissä vasta vuosien päästä.

3. laatukriteeri: Voidakseen vastata yhteiskunnan ja työelämän nopeisiin muutoksiin ammatillisen aikuiskoulutuksen tulee pyrkiä vaikuttamaan eriarvoisuutta vähentävästi tukien osallistujien tietoisuuden ja elämänhallinnan kasvua. "Muutoksen aikaansaaminen edellyttää aktivoitumista tietoiseen oppimistoimintaan. Muutos voi tapahtua vain aktiivisen toiminnan (subjektivoitumisen) kautta. Muutokseen tarvittavat tiedot ja taidot syntyvät oppimisprosessissa, joka on perusluonteeltaan sosiaalinen. Vuorovaikutuksellinen yhteisöllinen toiminta ylittää yksilöllisen toiminnan" (Ahola ym. 1989). Tämänkaltaisia koulutuksen tuloksia ei ole helppo mitata nykyisin menetelmin.

Ammatillinen kasvu ja työelämäsuhteen jäsennys ei ole pelkästään tiedollinen tapahtuma; Hyypän (1983) mukaan ammatillisen kehittyneisyyden kriteerinä voi pitää yhteyttä omaan kokemukselliseen puoleen ja toisaalta liittää se tehtävään liittyvään toimintaan. Tärkeää on paitsi ulkoinen, todennettava tieto (esim. ammatillisessa täydennyskoulutuksessa) myös sisäinen, subjektiivinen tieto, joka voi olla niin yksilöllistä kuin yhteisöllistäkin.

\section{LÄHTEET}

Ahola ym. 1989. Ohjaavan koulutuksen opetussuunnitelman laatimisen lähtökohtia. Muistio. Helsinki: ammattikasvatushallitus.

Aronowitz, S. \& Giroux, H. 1991. Postmodern education. Politics, culture and social criticism. Minneapolis, Oxford: University of Minnesota Press.
Castrén, P. 1992. Työnvälityksen, työvoimakoulutuksen ja vähän koko työvoimapolitiikankin tavoitteista sekä niiden mittaamisesta. Työpoliittinen aikakauskirja 1/1992. Helsinki: työministeriö, suunnittelusihteeristö.

Collins, M. 1991. Adult education as vocation. A critical role for the adult educator. London, New York: Routledge.

Giddens, A. 1981. Agency, institution and time-spaceanalysis. Teoksessa K. Knorr-Cetina \& A. Cicourel (eds.): Advances in social theory and methodology. Toward an integration of micro- and macrosociologies. Boston, London, Henley: Routledge \& Kegan.

Haavisto, T. 1991. Subjektius ja yhteistoiminta: Ohjaavan koulutuksen julkiteorian kehittelyä ja tarkastelua. Vaasan ammatillinen aikuiskoulutuskeskus.

Hyyppä, H. 1983. Avointen järjestelmien teoria työnohjauksen viitekehyksenä. Oulun yliopiston kasvatustieteiden tiedekunnan tutkimuksia 17/1983.

Katajisto, J. 1991. Muistioluonnos 16.10.1991 OECD:n raporttiin Overcoming disadvantage and improving access to education and training. Organization for Economic Cooperation and Development, Directorate for Social Affairs, Manpower and Education. Helsinki: opetushallitus.

Kivinen, O. \& Rinne, R. 1991. Mechanisms of education and access to higher education in Finland. Raportti OECD:n koulutuskomiteaa varten. Research Unit for the Sociology of Education. University of Turku. 22.4.1991.

Niinistö, K. 1984. Aikuiskoulutus ja sen evaluointi. Uusia sovellutuksia lähinnä tulkinnallisesta näkökulmasta. Valtion koulutuskeskus, julkaisusarja B nro 23. Helsinki: VaPK.

OECD 1990: Improving Access and Overcoming Failure. OECD Meeting of the Educational Committee at Ministerial Level 13-14 November. Draft.

Pasanen, H. 1992. Kriittisen teorian näkökulma aikuiskasvatukseen. Aikuiskasvatus 2/1992.

Pirsig, R. 1988. Zen ja moottoripyörän kunnossapito. Helsinki: Otava.

Silvonen, J. 1992. "Kritiikki vain häiritsee tehokasta opiskelua." - Opintojen pitkittymisdiskurssin ulottuvuuksia. Tiede ja edistys $1 / 1992$.

Rorty, R. 1991. Objectivity, relativism and truth. Philosophical papers, Vol. 1. Cambridge University Press.

Toiskallio, J. 1992. Yhteisopetus, opetuksen laatu ja opettaja. Luento THO:n opintopäivillä. Ammattikasvatus $5 / 1992$.

Wilenius, R. 1975. Kasvatuksen ehdot. Kasvatusfilosofian luonnos. Jyväskylä: Gummerus.

Virkkunen, J. 1992. Tulosmittarit johtavat harhaan. Helsingin sanomat 1.5.1992. 